\title{
オーストラリアの地理学
}

堤 純*+

\section{Geography in Australia}

Jun TSUTSUMI*+

\begin{abstract}
This paper presents an overview of geography in Australia. It answers three main questions. Does the teaching of geography in Australia focus on specific topics? How is geography taught in secondary schools? And, what differences are there in the approaches taken to geography in Australia and Japan.

In Australia, geography is first taught in year five at primary school level. The teaching of geography aims to provide background knowledge that is essential to understand both natural and human elements of the world and how they interrelate. This enables students to better understand the impacts of human beings on natural environments.

The teaching of geography in Australia is more advanced than it is in Japan. According to the website of the Institute of Australian Geographers, geography is taught at 18 of 41 universities in Australia. At these universities, geography programs are supported by a wide range of resources and include specialized research groups such as physical geography, GIS, remote sensing, and human geography. Some Australian universities have recently reformed their teaching systems. In this process, geography departments were merged with those of other disciplines, which resulted in a decline in the number of geographers. However, based on the above, geography is widely accepted as an academic subject in Australia.
\end{abstract}

Key words : Australia, geography in universities, GIS, geography skills, geography education キーワード : オーストラリア, 大学の地理学, 地理情報システム, 地理的スキル, 地理教育

\section{I. はじめに}

オーストラリアの社会と経済はイギリスの影響 を強く受けてきた。このことは，オーストラリア の地理学にもおおむねプラスに作用してきたと思 われる。オーストラリアには 6 州と 1 準州があ るが，それぞれの州を代表するような主要大学を 訪ねてみると, 10 名以上の地理学者が所属する 学部・学科も決して珍しくない。地理学者は文系
学部に所属することもあれば, 理学 (地球科学) 系や工学系に所属する場合もある。また, 都市計 画や地域計画, 持続的 (都市) 発展 (sustainable (city) development) などの分野についても, いわゆる日本の「土木」にあたる分野の研究者よ りも, 地理学者あるいは地理系の学部のスタッフ が関わることも珍しくない。

また，英語圈ということが主因であるが，オー ストラリアの大学ではスタッフや博士研究員に,

* 愛媛大学法文学部人文学科

+ 現所属：筑波大学生命環境系

* Department of Humanities, Faculty of Law and Letters, Ehime University, Matsuyama, 790-8577, Japan

+ Present address: Graduate School of Life and Environmental Sciences, University of Tsukuba, Tsukuba, 305-8572, Japan 
アメリカ，カナダ，ニュージーランドそしてイギ リス出身者の多いことが目を引く。英語圈での人 材の流動性が高いことはもともといわれており, オーストラリアの大学の卒業者がアメリカやカナダ の大学院に進学して博士の学位を取得したり, 中 国やインド生まれの研究者がアメリカやカナダで 博士の学位を取得した後に, 新天地のオーストラ リアの大学に職を得るということも稀なことでは ない。また，これは地理に限ったことではない が，北半球と季節が逆であることを利用して， 6 か月程度のサバティカル, あるいは研究休㗇を, 夏のオーストラリア $(9 \sim 2$ 月頃 $)$ で過ごすおも にイギリスからの研究者も珍しい存在ではない。

筆者はここ 10 年近くの間，年に $1 \sim 2$ 回のペー スでオーストラリアの各地に出向き，主としてメ ルボルンとシドニーの都市社会地理学的な研究に 従事してきた。本稿の目的は，オーストラリアの 地理学に関して, 筆者の目からみた学会組織, 大 学の様子, そして中学・高校における地理の概要 を紹介することである。

\section{II. オーストラリアの地理学会}

オーストラリア全土をカバーする学会組織と しては, Institute of Australian Geographers （IAG）がある。この学会は，1963 年から機関誌 『Australian Geographical Studies』(1 年に 4 冊) を刊行してきたが，2005 年（Volume 43）以降 から機関誌名を『Geographical Research』へと 変更した。この学会は自然地理学と人文地理学の 両方をカバーしており，とくに，自然一間シス テムの解明を目的とした自然地理と人文地理の研 究交流を促進することが機関誌の目的の一つでも ある。

また,IAGよりも古く, 由緒ある学会組織と しては Geographical Society of New South Wales がある。1927 年に設立されたこの学会は, 学会 名にニューサウスウェールズという州名が入って いるものの，オーストラリア国内に広く会員をも つ全国組織であり，機関誌の『Australian Geographer』を 1 年に 4 冊刊行している。

オーストラリアの地理学の研究動向を概観する

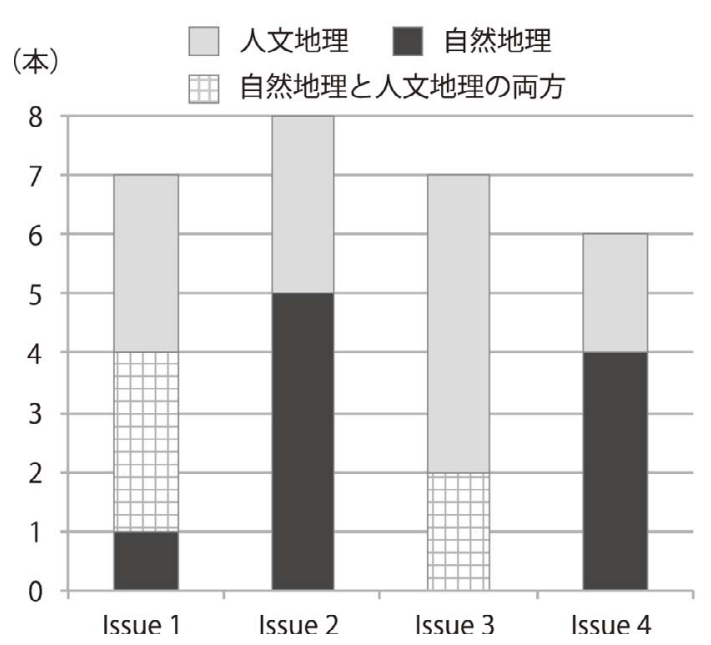

出典 http://onlinelibrary.wiley.com/journal/10.1111/(ISSN) 1745-5871

図 1 Geographical Research Volume 49 の掲載論文 のテーマ.

Fig. 1 Topics appearing in Geographical Research Volume 49.

ため, 『Geographical Research』の最新巻 Volume 49 （2011 年刊）の 4 冊の機関誌の掲載論文をみ てみると, 各号は 7 本程度の論説（papers）を 掲載していることがわかる。各論文の内容を大ま かに分けると，1号（自然地理 1 , 自然-人文 3 , 人文地理 3 編)， 2 号 (自然地理 5 , 自然-人文 0 , 人文地理 3 編)，3 号（オーストラリアの人口特 集号) (自然地理 0 , 自然-人文 $2, 人$ 文地理 5 編), 4 号（自然地理 4 , 自然一文 0 , 人文地理 2 編) であった（図 1）。2011年に掲載された 28 本の 論説のうち, 自然地理（生物多様性や海岸地形, 河川環境といった自然地理に特化した論文）は 10 編，人文地理は 13 編である。一方で，都市化 の進展にともなう水資源管理の必要性，都市近郊 の豊かな森林内の住宅開発とブッシュファイヤー の危険性, 観光開発と生物資源管理の協調の必要 性など，自然地理と人文地理にまたがる内容の論 文が 5 編掲載されていることは特筆すべきこと であろう。このように，自然一間の関係に踏み 込んだ論文が散見されるのは，厳しい自然環境と 隣り合わせで暮らすオーストラリア社会を映す鏡 ともいえるだろう。 


\section{III. オーストラリアの大学と地理学}

オーストラリアには表 1 に示すように 41 の大 学がある。それらのうち, 18 の大学において地理 学が教えられている (Institute of Australian Geographers, 2011)。オーストラリアの大学の トップ 10 にランキングされる大学 ${ }^{1)}$ にはすべて 地理学のカリキュラムがあり，ノーザンテリト リーを除く各州の州都にある主要大学では地理学 を学ぶことができる。この表によれば，地理学は 多くの大学において文系と理系にまたがり，「地 理科学」(Geographical Sciences) や「地理・ 環境科学」(Geography and Environmental Sciences),「地理 ·地域計画」(Geography and Planning）といった名称の講座に所属する例が 多いことがみてとれる。地理学が，明らかに伝統 的な文系学部, あるいは理系学部とわかる名称の 組織に属している例はごくわずかである一方, オーストラリアの大学における地理学は, 学際 的・総合的な学問として重要性が認知されている と考えられる。

ここでは，オーストラリアの大学のなかから 3 大学 (メルボルン大学, オーストラリア国立大学, モナーシュ大学) をとりあげ，地理学を専攻する 場合のカリキュラムの特徵について紹介する。

\section{1）メルボルン大学}

メルボルン大学では, 地理学は Melbourne School of Land and Environment $の$ Department of Resource Management and Geography (DRMG) に所属している (University of Melbourne, 2011)。この学科は 2008 年の学内改組 によって誕生したものであり, Melbourne School of Land and Environment の地理関係スタッフ と文学部所属の地理関係スタッフが合流して $1 つ$ の学科に再編されたという経緯をもつ。こうした 経緯とも関係して,この学科には地理学と資源管 理学, 園芸学が含まれており, 自然科学と社会科 学との学際的な領域を意識した研究・教育が進め られている。DRMGでは現代社会と環境問題と の関連，あるいは人間活動に起因する環境問題に ついて学ぶことを主眼としており，それらの諸問
題の形態が地域別や諸要因別にどのように異なる かについて興味関心が置かれている。とくに，地 球上の契緊の課題が重要視されている。たとえ ば, 都市緑化 (緑地と健康問題の関連), 防犯, 貧困，都市の水資源管理，地球温暖化による植生 や景観への影響，社会と政策・気候科学との相互 作用，政治経済学 (political ecology)，鉱産資源 管理，生物多様性などの課題などである。

メルボルン大学の地理学のスタッフは, 自然地 理学のスタッフの方が人文地理学のスタッフより も多いため, 気候変動や自然贸害，水資源管理な どに取り組むスタッフが数の上では多い。しか し, アジア・太平洋地域の経済問題, 豪中関係, 都市内部における民族多様化の諸問題, ジェン ダー地理学, 持続可能な都市などの研究も精力的 に行われている。

メルボルン大学の DRMG における, 地理学専 攻の学生（Geography major students）は, 自 身の興味関心に近い授業を組み合わせて単位を 積算していき, 取得単位に基づいて環境学学士 (Bachelor of Environments (Major in Environmental Geographies, Politics and Culture)), 文 学士 (Bachelor of Arts (Major in Geography)), 理学士 (Bachelor of Science (Major in Geography)) の 3 種類のいずれかの学士の学位を取得 できる。また，通常の学士号取得コースより 1 年 長く学ぶ honours, 理学修士 (地理学), 環境学 修士, 哲学修士 (Master of Philosophy), 博士 (PhD) などの学位も取得可能である。

\section{2) オーストラリア国立大学 (ANU)}

オーストラリア国立大学 (The Australian National University) では, 地理学のプログラ ムは文学部の学生向けに提供されている。ここで は, 人間と環境の相互作用 (human-environment interactions）が重視されており, 環境問題の解 決に向けた経済・社会的アプローチはもちろん, 天然資源管理や生態系管理のアプローチも重視さ れている。

オーストラリア国立大学の地理学専攻生は, 次 の（a）群から最大 12 単位，（b）群から最大 12 単位,（c）群から 18 単位以上を取得し, 合計 42 


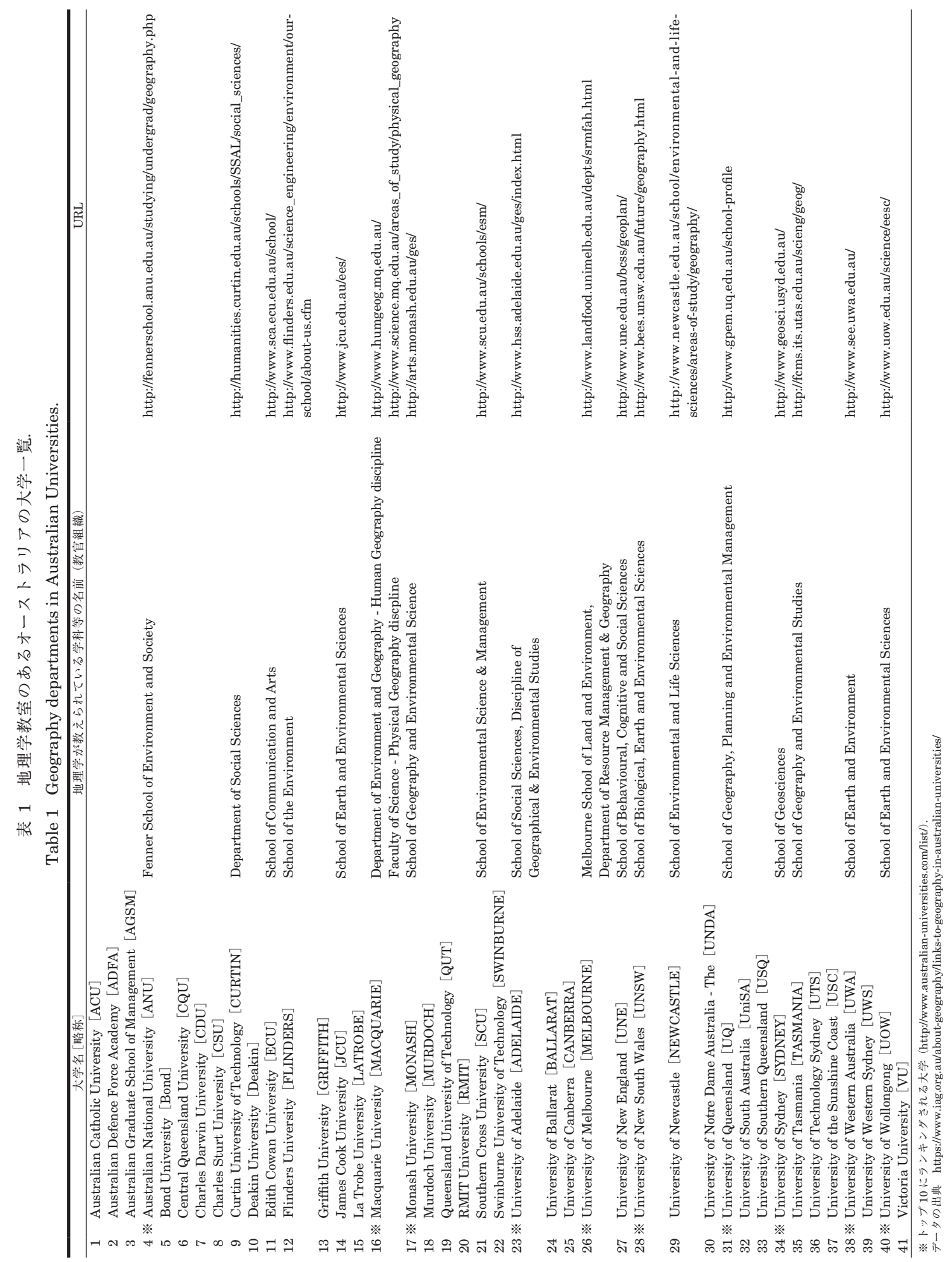


単位を取得することで, 文学士の学位が取得でき る。（a）群は全地球的な視点から捉えたマクロ スケールの地球環境問題やオセアニア地域の概 論,（b）群は気候, 環境問題, 人文社会環境, 計 量的手法, GIS, 水資源, 植生などの地理学関連 の各論, そして（c）群は気候変動や持続可能な 社会, 古環境の復元, 国際的な環境問題などに 関わる演習や実習である（Australian National University, 2011)。

オーストラリア国立大学では，上部組織である 人文社会, アジア・太平洋地域, 経済, 工学, 法 律, 医療・環境, 理学の 7 つのカレッジを中心 に，相互に関連づけられた学部，リサーチ・ス クール, リサーチ・センターらが組織化されてい る。かつてはリサーチ・スクールのレベルに, 研 究に従事する地理学者が在籍していたが, 現在で は学部教育を担うレベルの教育スタッフが在籍す るのみである。

\section{3) モナーシュ大学}

1960 年代に設立されたモナーシュ大学は, オーストラリアのなかでは比較的新しい大学であ るが，オーストラリア国内ではトップクラスにラ ンキングされる大学の一つである2)。地理学のス タッフは現在, 文学部の School of Geography \& Environmental Science（以下, GES) に所属し ている。モナーシュ大学では, 地理学専攻を意味 する「Geography major」の数は，必ずしも地理 の研究室に所属して論文を執筆した学生数とは一 致しない。

モナーシュ大学では「major」の要件は指定す る 8 単位の科目を修得することであり, 学生は 入学後にさまざまな「major」をとりながら自ら の興味関心を深めていく。「地理学専攻」のほか にも「社会学専攻」「心理学専攻」「会計学専攻」 などをもつ「二重専攻」（double majors）も珍し くない。モナーシュ大学の GES に所属する学生 数は, 2006 年には 1,337 人であったが, その後 2011 年には 1,781 人へと増加している。

筆者は, 2009 年 $3 \sim 9$ 月まで, 客員研究員と してモナーシュ大学の GES に在籍した。ここで は GES を事例として，オーストラリアの大学の
地理学担当教員の研究内容, 日常の研究生活, 大 学の雲囲気などを紹介する。

モナーシュ大学の GES は, (1)社会環境地理学, (2) GIS, (3)先住民の考古学, (4)自然地理学, (5) 都市経済地理学の主要 5 分野で構成されている。

(1)社会環境地理学の分野には, モナーシュ大学 Centre for Water Sensitive Cities のセンター長 でもあるレベッカ・ブラウン（Rebekah Brown） 教授をはじめ，クリスチャン・クル（Christian Kull）准教授ら 5 人の教官が所属している。こ こでは, 都市の水環境, 水資源管理, インド洋沿 岸や太平洋沿岸地域における植生や土地利用変化 とその環境への影響など，人文地理と自然地理に またがる領域が研究テーマである。人材の国際移 動も活発であり，アメリカやカナダ，北欧での勤 務経験のあるスタッフや博士研究員も珍しくな い。

(2) GIS 分野には，ジム・ピーターソン (Jim Peterson）准教授とシュアン・ジュー（Xuan

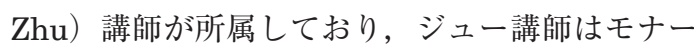
シュ大学の GIS センター長も兼務している。こ の分野に所属するアカデミックスタッフはこの 2 名であるが，ほかに日本の大学の技官にあたるよ うな技術スタッフが扔り, 学生や大学院生が GIS を学ぶ際のサポートにあたっている。

(3)先住民の考古学の分野は, $2007 \sim 2009$ 年 にかけてオーストラリア考古学会の会長を務めた イアン・マックニーヴン（Ian McNiven）教授を はじめ 3 人のスタッフから構成されている。こ の分野は, 考古学 (archaeology) の名称が使わ れているが, 実際の研究内容は歴史地理学や文化 人類学に近い。このグループの主要な研究テーマ は，海岸付近の先住民族の過去の居住特性の分析 や，パプアニューギニアやトレス海峡諸島周辺に おける過去の文化的交流の調査などである。

(4)自然地理学は現在 5 名のスタッフからなり, 森林域における水収支や二酸化炭素収支を専門と するジェイソン・ベリンガー (Jason Beringer) 教授, 地形学が専門のデイビッド・ダンカリー (David Dunkerley) 准教授，エルニーニョをは じめ気候変動解析の第一人者であるネヴィル・ニ 
コラス（Neville Nicholls）教授，オーストラリ アの乾燥地域の気候研究で著名なナイジェル・ タッパー（Nigel Tapper）教授らを擁している。 $2008 \sim 2009$ 年の教室改組により，自然地理学 グループの大半のスタッフは理学部の建物へと拠 点を移した。

(5)都市経済地理学の分野は, 多くの研究スタッ フの興味関心が集まる特徵がある。最も活発に 研究業績を上げているスタッフの一人，ハリプ リヤ・ランガン（Haripriya Rangan）准教授 を中心に, メルボルン大学の研究者らと共同で 「政治経済学研究グループ」(Political Ecology Research Group）を立ち上げ，オーストラリア， 東南アジア，南アフリカなどの地域を事例とし て, 政治, 経済, 貿易などのテーマに加え, 貧困 の問題にも積極的に研究関心を寄せている。

このように, GES のスタッフの研究内容は, 自然地理から人文地理まで幅広い分野に及ぶにも かかわらず，スタッフ間のコミュニケーションが よくとられている。オーストラリアの大学ではご くあたり前の習慣であるが，毎日午前 10 時半前 後になると，メールボックスやソファとともに冷 蔵庫やコーヒーメーカーが置かれたコモンルーム に人が集まりはじめ, 30 分〜 1 時間程度かけて モーニング・ティーを楽しむ。もちろん，授業や 会議があったり, 急ぎの要件のある場合はこの限 りではないが，筆者のみたところ，毎日多くのス タッフが入れ替わり集まって談笑していた印象が ある。アカデミックスタッフのみならず，事務官 や博士研究員, さらには筆者のような客員研究員 の異動があれば，このモーニング・ティーの賑や かな場が，オフィシャルな挨拶の場にもなる。ス タッフの誕生日や特別な記念日などには皆でお金 を出し合ってケーキが登場することも多々あっ た。

また，もう一つのコミュニケーションの場とし ては, 1 か月に $1 \sim 2$ 回のペースで, 昼休みを使っ てランチタイムセミナーを行っていることがあげ られる。ここで, 各自が取り組んでいる最新の話 題をざっくばらんに話題提供し, 自然地理も人文 地理も分け隔てなく意見交換を行う。例えば，森
林管理や野生生物の保護管理に関する話題提供が あれば，気象分野の研究者が近年の極端な干ばつ の影響を質問したり，あるいは都市に関心をもつ 研究者が, 郊外の森に近接した住宅地における ブッシュファイヤーの危険度について質問をす る。こうした自由な䨌囲気は, 自然地理と人文地 理の垣根を越えた共同研究を生み出す原動力にも なっているとの印象をもった。こうした，現代的 に要請の高い分野の研究者が多く在籍し, 自然地 理と人文地理の垣根を越えた実践的な学びが展開 されていることは, 同大における近年の地理学専 攻学生の増加の一因と考えられる。

また，多文化社会を反映するように，スタッフ やほかのメンバーの出身国も多様であった。例え ば，インド出身のランガン准教授は，インドの大 学を卒業した後, アメリカ・カリフォルニア大学 のロサンゼルス校で修士と博士の学位を取得し, 同大学バークリー校で博士研究員を 2 年間務め た後,メルボルンにある RMIT 大学の講師とし て着任。その後，モナーシュ大学に移籍して現在 に至っている。もともと英語圈の大学では人材の 流動性が高いといわれているが，オーストラリア の大学ではアメリカ, カナダ，イギリス，イン ド, そしてシンガポールとの間の研究者の異動は もとより, 博士研究員や客員研究員の受け入れ先 も多様である。さらにまた，卒業生についても地 元の市役所や州政府, 統計局などに多く就職して おり，メルボルンを中心に人材のネットワークが できている点も印象に残った。

このように，オーストラリアの大学において地 理学が比較的人気の高い実践的な学問として認知 されている背景には，大学に入学以前の中等教育 における地理の扱いにも特徴があると考えられ る。この点については，次章で検討する。

\section{IV．中・高校における地理の教科書の特徵}

ここでは, オーストラリアの中学校・高等学校 で使われている地理の教科書の内容をとりあげ, オーストラリアの中等教育における教科として の地理の重要性を紹介する。中学 (Secondary School) で学ぶ地理のワークブックとして『Skills 
表 2 オーストラリアの中学・高校における地理のワークブック『Skills in Australian Geography 2nd Edition』の学習内容.

Table 2 Contents of "Skills in Australian Geography 2nd Edition," a geography textbook used in secondary schools.

\begin{tabular}{|c|c|}
\hline 第一節（pp.2-28） & 地理の基礎的スキル（Geography skills bank） \\
\hline 1.1 & 地図 \\
\hline 1.2 & 縮尺 \\
\hline 1.3 & 緯度・経度, 時差 \\
\hline 1.4 & 方角, 方位, 象限 \\
\hline 1.5 & 標高 \\
\hline 1.6 & 地形の特徵 \\
\hline 1.7 & 地形図の読図 \\
\hline 1.8 & 航空写真, 衛星写真 \\
\hline 1.9 & フィールド・スケッチ \\
\hline 1.10 & 気候グラフ, 気候地図 \\
\hline 1.11 & グラフ \\
\hline 1.12 & 主題図 \\
\hline 1.13 & 統計の利用 \\
\hline 第二節（pp.29-69） & 地理的スキルを使ってみよう \\
\hline $2.1 \sim 2.20$ & $\begin{array}{l}\text { 地形図を使ったワーク（首都・キャンベラ, 観光地, } \\
\text { 都市再開発, 農業地域, 工業地域, 鉱業地域など） }\end{array}$ \\
\hline 第三節（pp.70-89） & オーストラリア地理の主要テーマ \\
\hline 3.1 & オーストラリアの国土の位置 \\
\hline 3.2 & オーストラリアの地形と砂漠 \\
\hline 3.3 & オーストラリアの気候 \\
\hline 3.4 & 自然災害 \\
\hline 3.5 & オーストラリアの植生 \\
\hline 3.6 & オーストラリアの人口 \\
\hline 3.7 & オーストラリアの先住民 \\
\hline 3.8 & オーストラリア人の居住地 \\
\hline 3.9 & 経済活動と雇用 \\
\hline 3.10 & 観光産業の発展 \\
\hline 解答 (pp.90-92) & \\
\hline
\end{tabular}

Kleeman and Peters（2007）により作成.

in Australian Geography 2nd Edition』をとり あげる（Kleeman and Peters, 2007）。このワー クブックは, 7 ～ 10 年生（日本の中 1 高 1 ) を対象に書かれたものであり，地図やグラフを用 いた地理的スキルの習得に主眼が置かれているこ とがわかる（表 2)。第一節で扱う「地理の基礎 的スキル」では, 小学校で学んだ個々のスキルを, 詳しい解説を通して確実に習得することを目指し ている。第二節では，オーストラリア国内から首
都, 観光地, 都市再開発, 農業地域, 工業地域, 鉱業地域などを含む 20 か所の事例が選定されて いる。加えて, 各項目について約 30 の質問が $\lceil$ Activity」として設定され，地形図の読図を通 してそれらの設問に答える形式がとられている。 第三節ではオーストラリア国内の今日的な課題を より深く掘り下げる内容になっている。小学校で も扱った気候や地質の特徵, 生物的な多様性, 先住民の歴史, アジア・太平洋地域への接近 


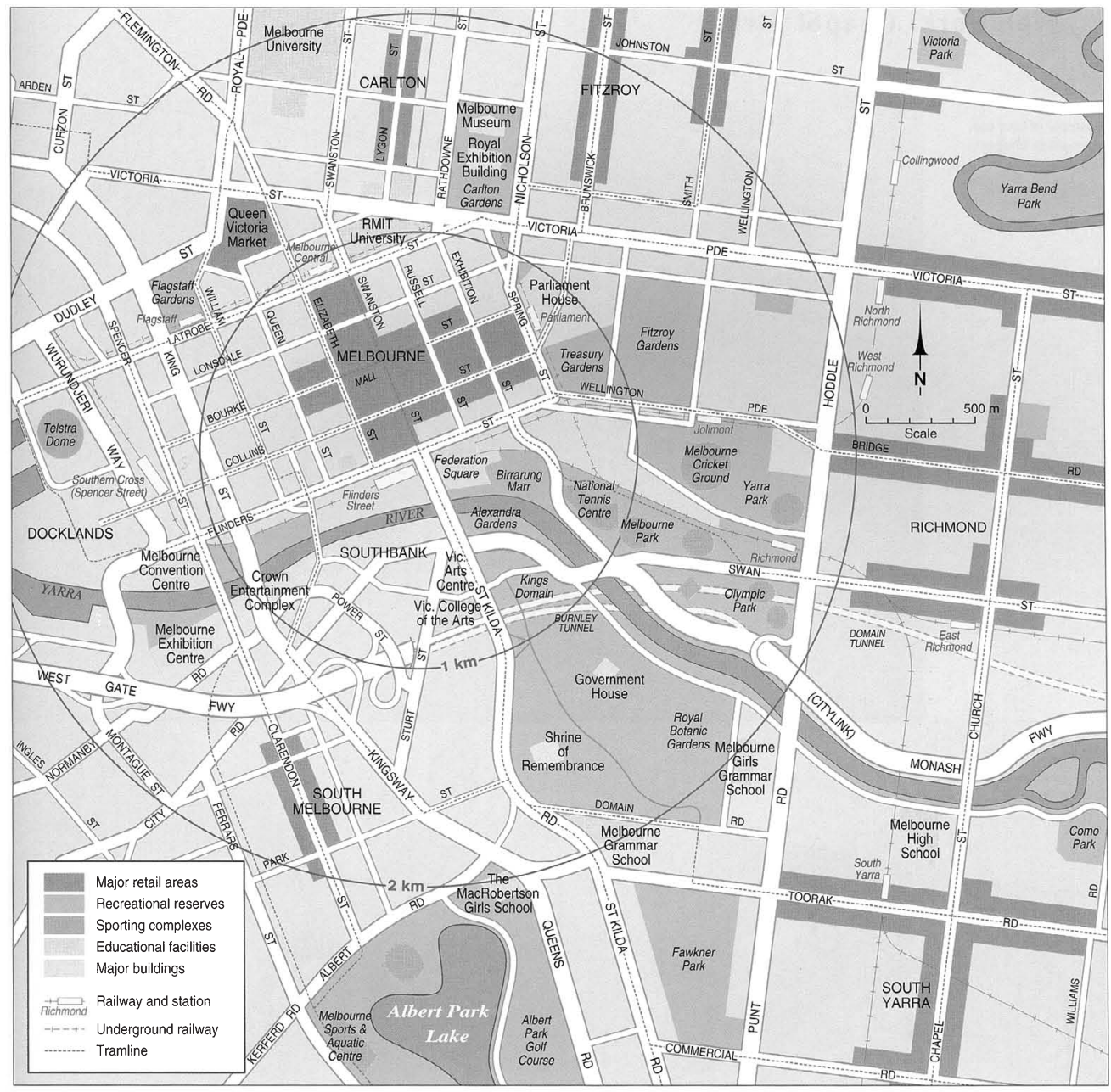

\section{ACTIVITIES}

1. Use figure 3.4.19 and a street directory to assess: a. any spatial associations that may be evident between the location of the strip-shopping precincts identified in the introductory paragraph, and the distribution of different types of public transport; and

b. the location of the nearest regional shopping centre, such as Chadstone, Southland Northland and Eastland, from these precincts.

2. Suggest reasons to explain the attraction of these strip-shopping precincts for shoppers, by identifying the differences that might be evident between them and a larger regional shopping complex.

3. Study the images in figure $\mathbf{3 . 4 . 2 0}$ on pages 194 and 195.

a. Describe the nature of the resource; b. Identify the geographic characteristics of the resource commenting on:

- the variety of land-use types,

- the width of the street,

- the width of the street frontages,

- the architectural design of the buildings and their possible age of construction,

- the heights of the buildings,

- the intensity of the development,

- evidence of the recycling of old buildings for a more modern function,

- the availability of car-parking spaces,

- accessibility by public transport,

- the range of goods and services on offer,

- the area's potential attraction for teenagers and young adults, and

- the possible cost of goods and services on offer
ABOVE

Figure 3.4.19

The location of innercity shopping strips

図 2 研究対象地域における商業地域の分布.

出典 Pask, R. (2007)

Fig. 2 Distribution of commercial precincts in the study area. 
Fieldwork: Chapel Street

\begin{tabular}{|l|c|c|c|c|c|c|c|c|c|c|c|}
\hline \multicolumn{10}{|c|}{ Monthly housing-Ioan repayment, Stonnington, 2001 } \\
\hline Dollars & $1-199$ & $200-399$ & $400-599$ & $600-799$ & $800-999$ & $1000-1199$ & $1200-1399$ & $1400-1599$ & $1600-1799$ & $1800-1999$ & $2000+$ \\
\hline Dwellings & 86 & 175 & 381 & 484 & 567 & 670 & 625 & 471 & 401 & 245 & 1756 \\
\hline
\end{tabular}
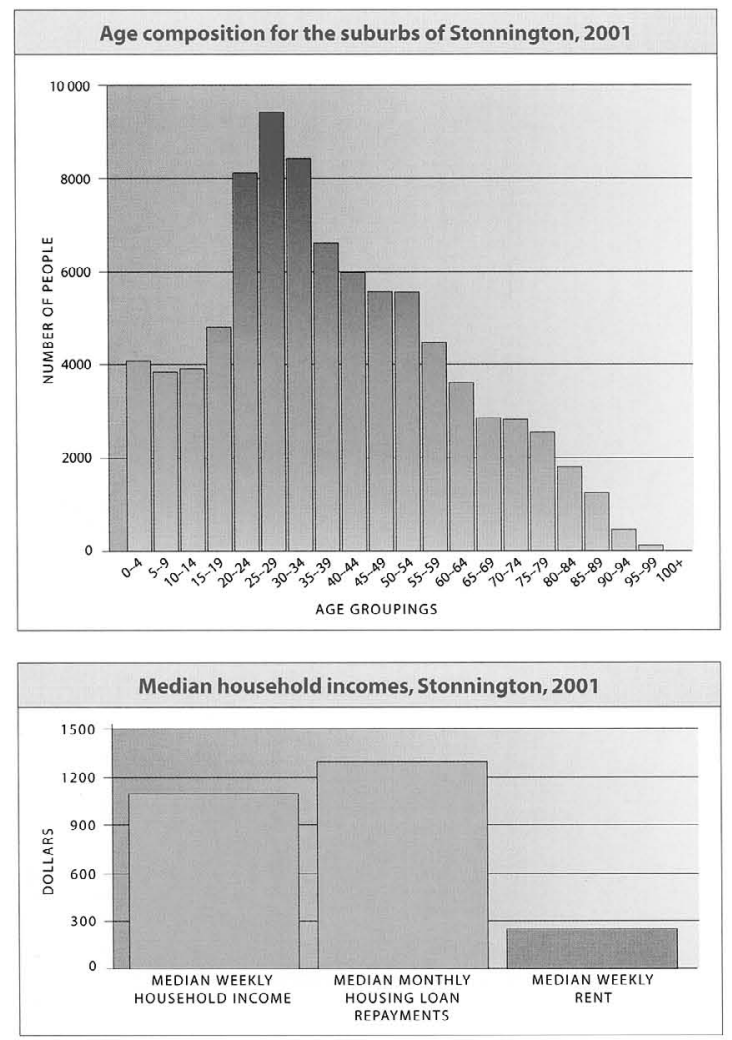

Figure 3.4.21 Sample data for the socio-economic level of the City of Stonnington

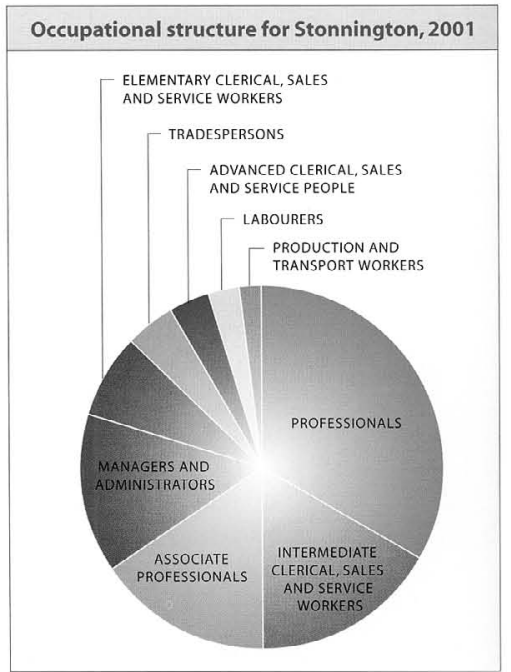

\begin{tabular}{|l|c|c|}
\hline \multicolumn{2}{|c|}{ Housing types in Stonnington and Melbourne, } \\
\hline & Stonnington & Melbourne \\
\hline $\begin{array}{l}\text { Percentage } \\
\text { of family } \\
\text { households }\end{array}$ & 55 & 73 \\
\hline $\begin{array}{l}\text { Percentage of } \\
\text { lone-person } \\
\text { households }\end{array}$ & 36 & \\
\hline $\begin{array}{l}\text { Percentage } \\
\text { of private } \\
\text { dwellings that } \\
\text { are separate } \\
\text { households }\end{array}$ & 34 & \\
\hline $\begin{array}{l}\text { Percentage } \\
\text { of private } \\
\text { dwellings that } \\
\text { are flats, unit or } \\
\text { apartments }\end{array}$ & & \\
\hline $\begin{array}{l}\text { Percentage } \\
\text { of private } \\
\text { dwellings } \\
\text { that are semi- } \\
\text { detached, } \\
\text { row or terrace } \\
\text { houses, or } \\
\text { townhouses }\end{array}$ & & \\
\hline
\end{tabular}

出典 Pask, R. (2007)

図 3 フィールドワークのまとめの例.

Fig. 3 Example of fieldwork report conducted in Chapel Street, Melbourne. 
（engagement）といった課題が，地図やグラフの 読解，「Activity」を通じてとりあげられている。

さらに，高校レベルの教科書として紹介する 『New Perspectives VCE Geography Units 1-4』 の内容は，かなり高度で，かつ専門的な印象であ る (Pask, 2007)。この教科書は大きく 4 部構成 をとり，第一節では自然地理，第二節では人文地 理的な課題が系統的に示された後，第三節では水 資源問題や都市問題などを事例としたフィールド ワークがとり扱われている。例えば，メルボルン 郊外（都心から約 $5 \mathrm{~km}$ ) のお酒落なショッピン グ・ストリートであるチャペル・ストリートを事 例地区とするフィールドワークを解説した章で は，準備から最後のまとめに至る過程を詳細に例 示している。はじめに, 調査地の選定のために, まず市域全体に相当する広域の地図を作成して商 業環境の変化を概観した後（図 2), 実際に郊外 の路面店や買い物客を対象とした聞き取り調查を 実施し, その内容を図表や地図としてまとめる (図 3)。オーストラリアでは, こうした具体的か つ実践的な活動が，高校の地理の内容にかなりの 分量盛り込まれている特徵がある。なお，最後の 第四節ではグローバル化の進展に伴う環境問題や 輸出入の課題，国際的な人口移動に関わる諸問題 などが扱われている。

筆者は地理教育の専門家ではないため, この章 で紹介したオーストラリアの地理をめぐる教育内 容の記述は適切ではないかもしれない。しかし, 誤解を恐れずに大まかな印象を述べれば，日本の 中学レベルの内容はオーストラリアの小学校高学 年で，また，日本の高校レベルの内容はオースト ラリアの中学 $1 \sim 2$ 年あたりで教えられている。 高校用の教科書として紹介した『New Perspectives VCE Geography Units 1-4』のように，高 校地理の授業では，生徒自身が調査課題を設定 し，現地調査を行なった上でレポートにまとめる 過程までが含まれている。これは，ともすれば日 本の大学において地理で卒論を書くレベルに匹敵 する内容が，オーストラリアでは高校の段階で普 通に扱われていることを意味する。また，オース トラリアの地理 (教育) は, 小・中・高を通して,
児童・生徒に考えさせる演習形式の課題が多く設 定されていたり，地図の運用能力を高める工夫が 随所になされている。オーストラリアの地理教育 でみられるこれらの点は, 日本の地理 (教育) と は大きく異なり，先進的であるといえるだろう。

\section{V. おわりに}

オーストラリアの大学は, 留学生数や社会人学 生も多く, 多種多様な学生が同じキャンパスで学 んでいる（堤・オコナー, 2008; Tsutsumi and O' Connor, 2011)。市役所の研究部門の職員が社会 人学生として大学の地理学教室で学び, 修士や博 士の学位を取得する例も珍しくない。また，市役 所や州政府の機関で有効に活用されている GIS の担当職員のなかにも，地理学教室を卒業した 者が多く存在する。本稿で紹介してきた内容は, オーストラリアの地理学のほんの一面にすぎない かもしれない。しかし，本稿で紹介した内容をみ るだけでも，オーストラリアでは地理学は広く社 会全般に受け入れられていると実感できる。オー ストラリアでは小学校の高学年から科目として 「地理」が登場し，その内容は基礎的なスキルの 習得から，学年が上がるごとに，隣国であるイン ドネシアやパプアニューギニアとの歴史的関係, 現代のアジア諸国との経済的つながり，広い国土 にみられる気候的，地質的，生物的な多様性の認 識，塩害化，森林減少などの諸問題の解説，そし て，国際的な人口移動や世界の貧困問題など，グ ローバルな内容へと発展していく。小学校高学年 の段階から，オーストラリアの特徴をグローバル なコンテクストのなかでとらえさせるカリキュラ ムは，実践的な学問としての地理の社会的認知に 貢献していると考えられる。

\section{謝 辞}

本稿を作成するにあたり，モナーシュ大学の Dr. Xuan Zhu 先生㧍よび茨城大学の葉 倩瑋先生からオー ストラリアの大学に関する貴重な情報をいただきまし た。記して感謝申し上げます。また, 本稿の脱稿後, III 章3)で紹介したモナーシュ大学のジム・ピーター ソン准教授がここ数年の病気療養の後, 2012 年 2 月に 
他界しました。ジムの屈託のない笑顔が目に焼き付い て離れません。謹んでご冥福を㧍祈りいたします。

\section{注}

1）トップ 10 にランキングされる大学

http://www.australian-universities.com/list/ [Cited 2012/1/31]。

2) 前掲注 1 参照。

$$
\text { 文献 }
$$

Australian National University (2011): Study@ANU 2011. http://studyat.anu.edu.au/2011/majors/ARTSMGEOG; overview.html [Cited 2011/9/30].

Institute of Australian Geographers (2011): Links to Geography Departments.

http://www.iag.org.au/about-geography/links-togeography-in-australian-universities/ [Cited 2011/ 9/30].

Kleeman, G. and Peters, A. (2007): Skills in Australian Geography 2nd Edition. Cambridge University
Press.

Pask, R. ed. (2007): New Perspectives VCE Geography Units 1-4. Geography teacher's association of Victoria Inc.

堤 純・オコナー ケヴィン (2008): 留学生の急増か らみたメルボルン市の変容. 人文地理, 60, 323340. [Tsutsumi, J. and O'Connor, K. (2008): Changes in Melbourne due to the rapid increase in international students. Japanese Journal of $\mathrm{Hu}$ man Geography (Jinbun Chiri), 60, 323-340. (in Japanese with English abstract) ]

Tsutsumi, J. and O' Connor, K. (2011): International Students as an Influence on Residential Change: A Case Study of the City of Melbourne. Geographical Review of Japan Series B, 84, 16-26.

http://www.jstage.jst.go.jp/article/geogrevjapanb/ 84/1/84_16/_article/-char/ja/ [Cited 2012/1/31].

University of Melbourne (2011): Study Geography. http://www.land-environment.unimelb.edu.au/ geography/ [Cited 2011/9/30].

(2011 年 10 月 24 日受付, 2012 年 3 月 21 日受理) 